\title{
THE RIGHT TO PICKET-
}

\section{TWILIGHT ZONE OF THE CONSTITUTION}

\author{
Edgar A. Jones, Jr. $\dagger$
}

Substantial questions were raised anew by the decision and opinions in Local Union No. 10, United Ass'n of Journeymen Plumbers v. Graham, ${ }^{1}$ questions which have proved to be hardy perennials. Does the Court still recognize a constitutionally protected right to picket? How is such a right to be rationalized and what limitations should be imposed upon its exercise? Indeed, should it ever have acknowledged such a right to exist?

It would surprise few people and please many if the Court were finally to resolve these questions by the simple expedient of overruling Thornhill v. Alabama, the case that started the whole furor in 1940 by declaring picketing to be a constitutionally protected means for the communication of ideas. Before the Court may be justified in cutting off the Thornhill doctrine, however, it would seem that those decisions which apply this doctrine should reveal a failure to achieve a workable rationale whereby "the practical administration of labor law" 3 can be accommodated to a conception of freedom of expression inclusive of the right to picket. The impression is widespread that those decisions failed to do just that. " [L]ying on the vague periphery of constitutional right, wherein speech and action are blended," 5 this form of expression discerned in the First and Fourteenth Amendments by the Thornhill Court has been subjected ever since to the undermining effect of doubts as to its legitimacy.

Without breaching the Thornhill doctrine and the cases which have amplified it, may the basic issues posed by the Graham case be

$\dagger$ Assistant Professor of Law, University of California, Los Angeles.

1. 345 U.S. 192 (1953).

2. 310 U.S. 88 (1940).

3. Local Union No. 10, United Ass'n of Journeymen Plumbers v. Graham, 345 U.S. 192,196 (1953).

4. See, e.g., Gregory, Labor and the Law 346-9 (rev, ed. 1949); 1 Teller, Labor Disputes and Collective Bargaining $\$ \$ 135-6$ (1940); Corwin, Book Review, 56 HARv. L. Rev. 484, 486 (1942); Gregory, Constitutional Limitations on the Regulation of Union and Employer Conduct, 49 MrCE. L. REv. 191, 197-207 (1950); Teller, Picketing-Free Speech, 3 VA. L. Werkry Dicta 53 (1950). See also Jones, Picketing and Coercion: A Jurisprudence of Epithets, 39 VA. L. REV. 1023, $1026 \mathrm{n} .19$ (1953) (hereinafter cited as Jones, $A$ Jurisprudence of Epithets).

5. Markham \& Callow, Inc. v. International Woodworkers of America, 170 Ore. 517, 599, 135 P.2d 727, 758 (1943). See Jones, A Jurisprudence of Epithets, supra note 4 , at 1039 et seq. 
resolved satisfactorily, which is to say, realistically and not merely by an artificial rearrangement of verbal symbols? The writer would venture to answer that question affirmatively. Indeed, it seems that the Court has already worked out the essentials of an analysis whereby picketing may be regulated fairly without jeopardizing its status as constitutionally-protected activity. It is hoped to demonstrate that here. ${ }^{6}$

The gist of the argument is this: (1) by its Thornhill decision the Court brought union activities under effective federal control at a time when Congress had not done so and as a matter of political reality was not apt to do so; (2) simultaneously, it preserved this medium of expression from unreasonable regulation by making applicable to it "clear and present danger" reasoning; (3) but in its most recent cases it has not heeded the caution formalized by that reasoning because it has failed to require that the enjoined activity be sufficiently linked by cause and effect to the policy insulated by the injunction. In turn, therefore, we shall consider, first, a recapitulation of the Thornhill decision and its judicial antecedents; second, how the Court has regulated the exercise of union economic power by its picketing decisions; third, how the Court, by adapting the "clear and present danger" test to picketing, has accommodated the economic consequences of effective picketing to its constitutional status; and, fourth, some concluding propositions.

\section{I.}

An insignificant proportion of the Supreme Court's business is concerned with labor picketing. It is possible, therefore, to trace the evolution of the right to picket through only a dozen cases decided over a thirty-three year period of economic turmoil. Yet these few cases have effectively set out the metes and bounds of state control over union combative strength. This is so because the picketer is organized labor's foot soldier. More often than not the fruits of the strike are won or lost on the picket line. Particularly is this true when other economic factors do not press management to prompt resolution of a labor dispute which has erupted into a work stoppage.

As late as 1931 there was serious doubt whether legislative means might be found to set off an area within which unions might utilize picketing to further their aims without running afoul of federal con-

6. See Gregory, Picketing and Coercion: A Conclusion, 39 VA. L. REv. 1067. (1953) (hereinafter cited as Gregory, $A$ Conclusion); cf. Rudd v. Dewey, 121 Iowa 454, 96 N.W. 973 (1903). See also, Jones, A Jurisprudence of Epithets, supra note 4; Gregory, Picketing and Cocrcion: A Defense, 39 VA. L. REv. 1053 (1953) (hereinafter cited as Gregory, $A$ Defense) ; Jones, Picketing and Coercion: $A$ Reply, 39 VA. L. REv. 1063 (1953) (hereinafter cited as Jones, A Reply). 
stitutional provisions. ${ }^{7}$ The Supreme Court had seemed in Truax $v$. Corrigan ${ }^{8}$ to reject the possibility of statutory legalization of picketing. It had done this in the names of "due process" and "equal protection" with reference to the property rights of the person picketed. Under the common law of many of the states at that time picketing was deemed to be tortious despite lack of violence. ${ }^{9}$

Thus it was thought in 1937 that the Court had relaxed considerably its antipathy to picketing when its judgment came down in Senn v. Tile Layers Protective Union. ${ }^{10}$ Senn, a small nonunion contractor in Wisconsin who laid tile with the help of two employees, was picketed by the union when he refused to sign an agreement which would effectively have barred him thereafter from laying tile himself. The State court refused to enjoin the picketing despite Senn's "due process" and "equal protection" arguments. In affirming the judgment of the Wisconsin court, Mr. Justice Brandeis held that the union tactic of seeking to deny Senn the opportunity to work on his own jobs was not a deprivation of liberty or property under the Fourteenth Amendment. Wisconsin had stated that the purpose of the union was lawful; the Court refused to upset the state's judgment.

Mr. Justice Brandeis saw nothing in the Federal Constitution to prevent statutory authorization of picketing. In a famous though ambiguous statement, he wrote: "Clearly the means which the statute authorizes-picketing and publicity-are not prohibited by the Fourteenth Amendment. Members might, without special statutory authorization by a State, make known the facts of a labor dispute, for freedom of speech is guaranteed by the Federal Constitution." 11

Mr. Justice Brandeis' basic position in Senn was that picketing was not prohibited by the Fourteenth Amendment. To find no prohibitive mandate in the Constitution obviously is not to find a protective mandate there. Indeed, the Senn holding suggests an interpretation which hardly could be thought to buttress a constitutional right to picket. It seems accurate to say that in 1937 picketing was susceptible

7. Chief Justice Taft had written of nonviolent, although verbally abusive, picketing: "Violence could not have been more effective. It was moral coercion by illegal annoyance and obstruction and it thus was plainly a conspiracy. . . . A law which operates to make lawful such a wrong as is described in plaintiff's complaint [the abuse being viewed as tortious conduct] deprives the owner of the business and the premises of his property without due process, and cannot be held valid under the Fourteenth Amendment." Truax v. Corrigan, 257 U.S. 312, 328 (1921). See Hellerstein, Picketing Legislation and the Courts, 10 N.C.L. Rev. 158, 185 (1932).

8. 257 U.S. 312 (1921).

9. See Gregory, $A$ Defense, supra note 6 , at 1054. .

10: 301 U.S. 468 (1937). See Gregory, A Defense, supra note 6, at 1058.

11. Senn v. Tile Layers Protective Union, 301 U.S. 468, 478 (1937). Compare Gregory, $A$ Deferuse, supra note 6 , at 1061 , with Jones, $A$ Reply, supra note 6 , at 1065. 
either to statutory authorization or, by necessary implication, to outright prohibition. That would hardly seem to evidence an equation of picketing and speech by Mr. Justice Brandeis. "If Wisconsin could permit such picketing as a matter of policy," said Mr. Justice Frankfurter in 1950, "it must have been equally free as a matter of policy to choose not to permit it. . . ."12 Whether or not compatible with the Brandeis dictum, assumed by most to tie picketing to free speech, it is clear enough that Mr. Justice Frankfurter's conclusion is in accord with the foregoing analysis of the Senn holding.

But that which in 1937 could have been authorized or prohibited at the whim of the state legislature became impossible of statutory prohibition rather abruptly in 1940. This striking inversion of premises was effected by the Supreme Court in Thornhill v. Alabama ${ }^{13}$ when it found that the Federal Constitution prevented the legislature of Alabama from prohibiting picketing. This decision elevated the right to picket to the status of a First Amendment "freedom," imposing upon the Court the responsibility thereafter of treating a picketer with the same relative precaution as it does a soapbox speaker, a newspaper editor, or a Jehovah's Witness.

Despite such ambient phrases as "communication of ideas," "the right of free discussion," "freedom of discussion," along with citations of John Milton, the Continental Congress and Mr. Justice Brandeis, Mr. Justice Murphy wrote a much more guarded opinion than is generally credited to him. By it, he carefully limited this new-found right. The most important limitation was the applicability of the "clear and present danger" test. "Abridgement of the liberty of such discussion can be justified only where the clear danger of substantive evils arises under circumstances affording no opportunity to test the merits of ideas by competition for acceptance in the market of public opinion." 14 This right, said the Court, like all rights of employers and employees to participate in the economic life of society, may be modified or qualified to serve the common good. ${ }^{15}$ But there was a caution to be observed. "This is but an instance of the power of the State to set the limits of permissible contest open to industrial combatants. . . . It

12. International Brotherhood of Teamsters Union v. Hanke, 339 U.S. 470, 4767 (1950). Cf. Thornhill v. Alabama, 310 U.S. 88 (1940), where Alabama chose not to permit picketing but the choice was rendered nugatory.

13. 310 U.S. 88 (1940). Mr. Justice McReynolds was the sole dissenter. It is interesting to note that Justices Black, Frankfurter, Douglas and Reed voted with Chief Justice Hughes and Justices Stone, Murphy and Rutledge for the Thornhill decision. Perhaps it should be added too that it was not Mr. Justice Murphy's opinion that created the constitutional right to picket; it was the decision for which the eight justices voted.

14. Id. at 104-5.

15. Id. at 103 . 
does not follow that the State in dealing with the evils arising from industrial disputes may impair the effective exercise of the right to discuss freely industrial relations which are matters of public concern." ${ }^{16}$

In addition to the "clear and present danger" test, the Court required that in order to be privileged the "discussion" must both be peaceful and truthful. ${ }^{17}$ Further, the Court ruled out instances of "picketing en masse or otherwise conducted which might occasion such imminent and aggravated danger" to the interests of the state in the preservation of peace and the protection of its citizens' lives, privacy and property "as to justify a statute narrowly drawn to cover the precise situation giving rise to the danger." 18

This then was the manner and form in which the right to picket was set in the First Amendment litany. It apparently was viewed as an aspect of speech. The "clear and present danger" test, as carefully and fully restated in Mr. Justice Murphy's opinion, was to apply, and presumably the Court's other speech cases were to constitute precedents for its picketing cases.

\section{II.}

There has always been speculation as to why the Court did what it did in the Thornhill case. ${ }^{19}$ As with classroom attempts to distinguish disparate cases under one "rule," the hazard to be avoided is that of an unrealistic and a priori theoretical pattern superimposed upon the decisions to justify doctrinaire preconceptions. As might be expected, that hazard is accentuated in an analysis of the Court's labor picketing decisions.

16. $I d$. at $103-4$.

17. Id. at 104 .

18. Id. at 105. Quite aside from the activity of picketing, although sometimes confused with it, is a pressure device sometimes misleadingly referred to as the "phantom" or "invisible picket line." Utilized when manufacturing plants are involved which are located on the fringe of population centers, this device consists simply of a telephone call or letter or conversational notification to other labor organizations of the fact that "picketing" of the plant has been "declared." Of this Professor Armstrong observes: "This calls union disciplinary control promptly into action. Union members are ordered not to deliver goods to or from the picketed establishment and not to patronize it directly or to buy its products elsewhere. All this is of course implicit in patrol picketing as well. Equally of course all this is something quite aside from picketing's free speech aspect." Armstrong, Where Are We Going With Picketing?, 36 CALIF. L. REv. 1, 32 (1948). This seems also to be aside from picketing itself. The so-called "invisible picket line" actually has nothing to do with the activity of picketing. It is an attempt to call into being sympathetic secondary pressures which, if successfully invoked, would constitute a secondary boycott. Neither ought it have anything to do with the constitutional legitimacy of so-called "patrol picketing," insofar as such activity might be encompassed by the right to picket.

19. See, e.g., Gregory Constitutional Limitations on the Regulation of Union and Employer Conduct, 49 MIICH. L. Rev. 191, 198 et seq. (1950); Smith, The Supreme Court and Labor, 1950-1953, LABOR Relations Law, A.B.A. REP. 21, 24 et seq. (1954). 
It has been observed that the Thornhill Court may have thought to achieve a national common law of labor relations. ${ }^{19 a}$ If the Court was so minded in 1940, there could hardly be a better means to attain this objective than a constitutional right to picket. It could be used to expand or contract the degree of insulation against state regulation according to felt necessities expressed in terms of "clear and present danger" reasoning. In any event, whether or not as a result of such omniscience, it is the point of this article that that is the present situation.

But it is generally assumed that the regulatory purpose of the Thornhill Court was a good deal less flexible, that the Justices intended thereby simply to make the states safe for unions. ${ }^{20}$ That supposition has had a great influence on subsequent criticism of the Court's supposed defection from its original position. We may briefly examine some facts, however, which appear to cast at least enough doubt on the validity of that assumption as to cause us to reappraise the decisions for a possible indication of an underriding flexible approach which hitherto may not have been made explicit.

Consider some of the economic and political factors which existed in 1940 of which the Court was undoubtedly quite mindful. ${ }^{21}$ Congress in the 1935 Wagner Act ${ }^{22}$ had deliberately left unions unhampered by national regulation so as to encourage their growth. But in 1936 the unanticipated fracture of the AFL and appearance of the militant CIO upset a basic political assumption of the Wagner Act. The results were widespread employer-bruising jurisdictional battles, and the acceleration of the general strengthening of the labor union movement due, in part, to that competition..$^{23}$ The imbalance of national legislation which corralled only employers may have seemed to warrant by them a kind of rough equalization which would also assure an effective and continuing adjustment of the competing interests of labor and management unhampered by local status quo pressures tending to rigidity. It was not foreseeable politically when Thornhill was decided in 1940 that Congress would amend the Wagner Act ${ }^{24}$ to take cognizance of the stresses

19a. Gregory, supra note 19, at 197-99.

20. E.g., Gregory, $A$ Defense, note 6 supra, at 1054: "But the Supreme Court apparently felt impelled to do a hurry-up job of making the entire country safe for peaceful picketing, both local and interstate."

21. See Gregory, Book Review, 36 VA. L. Rev. 409 (1950).

22. 49 STAT. 449 et seq. (1935), 29 U.S.C. $\$ 151$ et seq. (1946).

23. See Gregory, Labor and tHe Law 224-8 (rev. ed. 1949).

24. The Smith bill to amend the Wagner Act passed the House of Representatives on June 7, 1940, by a vote of 258 to 129 , but died because of Senate inaction. See Teller, Labor Legislation in the 83d Congress, LaboR Relatrons Law, A.B.A. REP. 8, 9 (1954). 
and strains caused by this altered structure of union economic power and industrial strife. . Unless the Court were simply to cloister itself behind Erie R.R.v. Tompkins, ${ }^{25}$ refusing to do other than apply state law in picketing cases, the "tour de force implicit in establishing peaceful picketing as a form of speech or communication" 26 may have appeared as a practical necessity in the Holmesian sense ${ }^{27}$ in order to assure at least a minimum of coherence in the overall pattern of the Court's labor decisions.

It would doubtless be thought somewhat novel at this date to suggest that the Court may have sought by its Thornhill decision not so much to protect unions ${ }^{28}$ but to restrain the more assertive of them as the Wagner Act restrained unduly aggressive employers. But the provocation was there ${ }^{29}$ and, whatever may have been the state of mind of the Justices, that does describe accurately the practical and logical effect of Thornhill as is apparent from the decisions which have followed it. That decision brought into the area of national control the conduct of the "other half" of labor-management disputes. It enabled the Court to review in terms of unlawful conduct-i.e., the "clear and present danger" test-the efforts of the states to regulate union conduct in terms of ends as well as means. Because of the decisive importance of picketing to labor in achieving its aims, this process of allowance and disallowance may indeed have seemed a natural. It was probably as good a control situation as could be evolved by the Court if it felt the need both for some kind of balance in responsibility and a measure of uniformity in regulation. The task was not too difficult as there was precedent of a sort; after all, Mr. Justice Brandeis had already noted the element of communication in picketing. All the Court had to do was to start looking at picketing through the Brandeis dictum. It set the focus by means of the Thornhill decision. The process of adjustment of interests thereby made possible began immediately after the initial establishment of the constitutional premise and has continued uninterrupted through the most recent of its picketing decisions.

But, to pin this all down, let us examine the post-Thornhill decisions, stepping temporarily outside the freedom-of-expression prob-

25. 304 U.S. 64 (1938). Has the dilemma of the 1940 Court been sufficiently appreciated as it matched th. 1938 Erie decision against the 1937 Senm precedent? See Senn v. Tile Layers Protective Union, 301 U.S. 468 (1937).

26. Gregory, op. cit. supra note 23, at 198.

27. Holmes, The Common Law 1 (1881).

28. See Gregory, supra note 19, at 198-9. Perhaps I should note that the utility of this hindsight analysis will turn not so much on whether it describes what did move the 1940 Court as upon what might move the 1954 Court.

29. See Gregory, op. cit. supra note 23, at 289 et seq. 
lem so that we may view them solely as economic documents. The cases appear to be divided into two different economic groupings separated by a span of five years (1944-1948) when picketing was not before the Court. ${ }^{30}$ The Szeing, ${ }^{31}$ Ritter's Cafe, ${ }^{32}$ Wohl, ${ }^{33}$ and Angelos $^{34}$ decisions comprise the first group. ${ }^{35}$

In the Swing case, the state sought to limit the allowability of picketing to a dispute between the employer and his employees. It accordingly forbade organizational picketing where the employees did not wish to join the union. This, the Court held, it could not do. Mr. Justice Frankfurter expressed it thus:

"A State canniot exclude workingmen from peacefully exercising the right of free communication by drawing the circle of economic competition between employers and workers so small as to contain only an employer and those directly employed by him. The interdependence of economic interest of all engaged in the same industry has become a common-place. . . . The right of free communication cannot therefore be mutilated by denying it to workers, in a dispute with an employer, even though they are not in his employ." 36

The decision required that there be some broader measure of allowance than the relationship of employer and employee. The opinion sug-

30. Compare Smith, supra note 19, at 28 n.20: “. . . the committee saw in the 1950 decisions a clear indication that the Court's attitude toward picketing had shifted. ('Picketing can no longer be equated to free speech')." An attritional effect upon doctrine of changes in personnel could be involved. Chief Justice Vinson replaced Chief Justice Stone in 1946. Justice Minton came on after the death of Justice Rutledge in 1949, as did Justice Clark in place of Justice Murphy that same year. Justice Burton replaced Justice Roberts in 1945.

31. AFL v. 'Swing, 312 U.S. 321 (1941). (1942).

32. Carpenters \& Joiners Union of America v. Ritter's Cafe, 315 U.S. 722

33. Bakery \& Pastry Drivers \& Helpers Local v. Wohl, 315 U.S. 769 (1942).

34. Cafeteria Employees Union v. Angelos, 320 U.S. 293 (1943).

35. Although Milk Wagon Drivers Union of Chicago v. Meadowmoor Dairies, Inc., 312 U.S. 287 (1941) may be read as unduly restrictive of a constitutional right to picket, it raises problems of violence and police enforcement which set it apart from this discussion. See also Hotel \& Restaurant Alliance v. Wisconsin Employment Relations Board, 315 U.S. 437 (1942). Carlson v. California, 310 U.S. 106 (1940), decided the same day as Thornhill v. Alabama, 310 U.S. 88 (1940), was substantially a companion decision to the Thornhill case. Not discussed herein are the following cases: NLRB v. International Rice Milling Co., 341 U.S. 665 (1951) ; NLRB v. United Denver Bldg. \& Construction Trades Council, 341 U.S. 675 (1951) ; Local 74, Brotherhood of Carpenters \& Joiners of America v. NLRB, 341 U.S. 707 (1951); Montgomery Bldg. \& Construction Trades Council v. Ledbetter Erection Co., 344 U.S. 178 (1952).

The second group of post-Thornhill cases to be examined infra are comprised of Giboney v. Empire Storage \& Ice Co., 336 U.S. 490 (1949) ; Hughes v. Superior Court of Cal., 339 U.S. 460 (1950) ; International Brotherhood of Teamsters Union v. Hanke, 339 U.S. 470 (1950); Building Service Employees Int'l Union v. Gazzam, 339 U.S. 532 (1950); International Brotherhood of Electrical Workers v. NLRB, 341 U.S. 694 (1951); Local Union No. 10, United Ass'n of Journeymen Plumbers v. Graham, 345 U.S. 192 (1953).

36. AFL v. Swing, 312 U.S. 321, 326 (1941) (italics added). 
gested the possibility that the unity of interest of those engaged in the same industry might be an appropriate measure of allowability.

A year later Mr. Justice Frankfurter had occasion to elaborate the unity of interest idea he had broached in the Swing opinion. It became the basis for the decision of Carpenters \& Joiners Union $v$. Ritter's Cafe. ${ }^{37}$ He stated the facts and issue briefly:

"In the circumstances of the case before us, Texas has declared that its general welfare would not be served if, in a controversy between a contractor and building workers' unions, the unions were permitted to bring to bear the full weight of familiar weapons of industrial combat against a restaurant business, which, as a business, has no nexus with the building dispute but which happens to be owned by a person who contracts with the builder. The precise question is, therefore, whether the Fourteenth Amendment prohibits Texas from drawing this line in confining the area of unrestricted industrial warfare." 38

The doctrine to be drawn from the Swing language and the Ritter's Cafe decision bears so marked a resemblance to the "labor dispute" reasoning of cases interpreting the anti-injunction acts ${ }^{30}$ that some concluded the Court had now incorporated Norris-La Guardia Act ${ }^{40}$ concepts in the First Amendment. ${ }^{41}$

What is established at this point is that the Court would not allow a state to contain picketing within the employer-employee relationship, but would allow states to prevent unions from ranging combatively beyond the bounds of interdependence of economic interest. Thus the Court would permit the state to bar secondary pressure reaching outside the affected industry. Would the Court render vulnerable secondary pressures within the area of economic interdependence?

In the Wohl case, ${ }^{42}$ which arose later that term, the Court indicated that states were not free to proscribe secondary pressures as such but only those which had repercussions upon the interests of strangers to the issue. Presumably a stranger was one outside the bounds of interdependent economic interest. The dispute in Wohl involved the refusal of self-employed peddlers to conform to union hours; the picketing was directed at the suppliers and customers (retail

37. 315 U.S. 722 (1942).

38. $I d$. at 726 (italics added).

39. See Goldfinger v. Feintuch, 159 Misc. 806, 813, 288 N.Y. Supp. 855, 863 (Sup. Ct. 1936), rev'd, 250 App. Div. 751, 295 N.Y. Supp. 753 (1st Dep't), modified, 276 N.Y. 281, 11 N.E.2d 910 (1937).

40. 47 STAT. 70 (1932), 29 U.S.C. $\$ 101$ et seq. . (1946). See particularly 47 Stat. 73 (1932), 29 UU.S.C. \$113 (1946), for "labor dispute" definitions.

41. See Gregory, op. cit. supra note 23, at 200-1 ; Ratner and Come, The NorrisLa Guardia Act in the Constitution, 11 GEO. WASH. L. REv. 428 (1943).

42. Bakery \& Pastry Drivers \& Helpers Local v. Wohl, 315 U.S. 769 (1942). 
shops) of the peddlers. By its decision, the Court allowed pressures to be generated against both the peddlers primarily involved and the small retailers who dealt with them. These latter, though subjected to secondary pressure, had an economic stake in the dispute involving the peddlers and so could be deemed to be in unity of interest with the disputants. The retailers were not like the owner of Ritter's Cafe who sought merely to construct a building dissociated from his restaurant and was not thereby deriving added profit in his business by dealing with nonunion rather than union people. If these small bakery shops wanted to avail of a price differential based in part at least on the lower overhead of nonunion peddlers, they would simply have to put up an economic fight for it if challenged by the union.

The Angelos case ${ }^{43}$ came up the following year. No secondary pressure was involved. The union picketed a cafeteria operated by its owners without any employees. Angelos came off no better than had Senn six years earlier, but the two cases were differently cast. Both recognize a legitimate "labor dispute" in the case of a picketed selfemployer, which simply means that the winner is to be determined by the economic survival of the fittest. But in 1943 the Court said that the state could not prevent a union from picketing a sole proprietor to induce him to employ union men despite his contention that he neither needed nor wanted to hire any help whatsoever. In 1937, on the other hand, the Court had said there was nothing in the Constitution which precluded a state from allowing such picketing.

Note well the change in the role assumed by the Court. Mr. Justice Brandeis had declined the role of umpire in 1937. He had instead adopted the attitude of a nonintervening bystander. If the state wanted to allow that kind of thing, well and good. If it preferred not to recognize it as lawful conduct, that too was up to it as a matter of policy. In either event, under the Brandeis reasoning, the Supreme Court would not substitute itself for the state as the policy formulator. Of course that was changed in 1940 by the Thornhill decision, which is why we find the Court thereafter talking and acting like an umpire rather than looking on as a bystander, the role Mr. Justice Brandeis had cast for it in 1937.

Four cases and three years after Thornhill, then, we may say that the Court was actively discharging the responsibility it had assumed by that decision. The Taft-Hartley Act was still in the unforeseeable future in $1943^{44}$ but the Court in the Swing, Ritter's Cafe, Wohl, and Angelos decisions had already in fact established a national pattern of

43. Cafeteria Employees Union v. Angelos, 320 U.S. 293 (1943).

44. See Teller, supra note 24 , at 8 et seq. (1954). 
allowable union conduct which, but for the Thornhill case, it could not have done. The effect was to protect those employers from harm who had no economic stake in the dispute in which the picketing union sought to embroil them. The Court thus set up ground rules of fairness which Congress, even had it been so inclined, may well have felt politically incapable of achieving in the early Forties.

During the extended lull (1944-1948) in the Supreme Court's consideration of picketing cases, three major developments in our economy took place. Unions grew a great deal stronger, in part at least because of policies of the War Labor Board. ${ }^{45}$ The Court amplified its conceptions of "interstate commerce" and federal preemption." ${ }^{66}$ And, in 1947, Congress enacted the Taft-Hartley Act. ${ }^{47}$

If the Court in 1940 sought to establish federal control over union aims and conduct, if it had hoped thereby to work toward a reasonable degree of fairness and national uniformity in the accommodation of the competing interests of labor and management, these purposes had been largely achieved by 1949, initially by the Szeing, Ritter's Cafe, Wohl, and Angelos decisions and, finally, by the enactment in 1947 of the Taft-Hartley Act and its subsequent judicial interpretation in a setting of relatively unlimited preemptive powers over commerce.

If that were true as of 1949 , and still considering the picketing cases solely as economic documents, it would seem reasonable to expect the Court to resume its seat in the stands. It would seem equally reasonable to expect that it would not surrender its entitlement to step in for a bit of relief umpiring should the occasion arise. Whatever may have been the judicial motivations, it is a fact that the Court's picketing decisions since that lull have enabled the states (and Congress) to pursue their own ways undeterred by the Court's Swing through Angelos decisions. State policy has been frustrated only when deemed preempted by congressional legislation. ${ }^{48}$

The second post-Thornhill group of cases dealing with state regulation of picketing started off with Giboney $v$. Empire Storage \& Ice Co.49 The Missouri Supreme Court had held that picketing could be enjoined where retail ice peddlers picketed a wholesaler to get an agreement from him not to sell ice to nonunion retail peddlers. The state court found such an exclusive compact would be in restraint of trade

45. See Gregory, Book Review, 36 VA. L. Rev. 409 (1950).

46. See Wickard v. Filburn, 317 U.S. 111 (1942) ; Hill v. Florida, 325 U.S. 538 (1945). Cf. Garner v. Teamsters Union, 346 U.S. 485 (1953).

47. Labor-Management Relations Act, 61 STAT. 136 (1947), 29 U.S.C. §151 et seq. (Supp. 1952).

48. See, e.g., Garner v. Teamsters Union, 346 U.S. 485 (1953).

49. 336 U.S. 490 (1949). 
or competition in violation of its antitrust statute. There was no question but that there was a unity of interest among the parties involved. As a matter of fact, there was a marked resemblance in the facts to $W o h l$ which had also involved peddlers. But the Court found an added element here. Mr. Justice Black held the Giboniey facts not disposed of by Wohl because of the presence in Giboney of an "unlawful combination" to violate Missouri's antitrust law.

Of course, the Court could have refused to worry about whether a state antitrust statute was incidentally violated by a labor union's pursuit of economic gain within the ambit of unity of interest. Indeed, because of the element of concerted action in all labor union activity, it has been suggested that the Court may have indicated to the states that it might allow the virtual elimination of secondary pressures from labor-management disputes insofar as picketing effectuates such pressures. ${ }^{50}$ States then would need only to make findings of restraint of trade based on the traditional free trade statutes aimed at both employers and organized employees to render the picketing vulnerable.

If Giboney might have been considered as an isolated phenomenon because of the free trade policies involved, the Court's May 8, 1950, picketing decisions completely dispelled any such misconception. Had Hughes ${ }^{51}$ been the sole decision handed down that day, however, it too might reasonably have been looked upon as limited to its own special situation, racial picketing. Whether or not a state will allow the eruptive hazard of racial picketing to exist in local circumstances ought certainly to be within its police power to determine. "In disallowing such picketing," Mr. Justice Frankfurter wrote, "States may act under the belief that otherwise community tensions and conflicts would be exacerbated." 52

But there was no mistaking what the Court did in the next two decisions read that day, both concerning regulation of picketing by the State of Washington. Mr. Justice Frankfurter stated the issue in the Hanke $^{\text {b8 }}$ case:

50. See Gregory, supra note 19, at 204-5.

51. Hughes v. Superior Court of Cal., 339 U.S. 460 (1950).

52. Id. at 464 .

53. International Brotherhood of Teamsters Union v. Hanke, 339 U.S. 470 (1950). The decision also disposed of Automobile Drivers \& Demonstrations Union v. Cline, No. 364, also up from the Supreme Court of Washington. In the Cline case the appellee similarly said that he could not abide by the limitation on business hours sought to be imposed on self-employer members, withdrew from membership, and was picketed. Two picketers patrolled peacefully with sandwich signs stating Cline was "unfair" to the union. In this case, as in Hanke's, a picketer also wrote down the automobile license of the patrons. But here, in contrast to Hanke's case, when patrons asked why their licnse numbers were noted by the picketers, the answer was, "You'll find out." Quaere: whether the two cases were thereby distinguishable to such a degree as to have warranted separate treatment? 
"The question is this: Does the Fourteenth Amendment of the Constitution bar a State from use of the injunction to prohibit the picketing of a business conducted by the owner himself without employees in order to secure compliance by him with a demand to become a union shop?" 54

This was Angelos and, in part, Wohl. But five years of inactivity had apparently enervated those decisions.

"In those cases, we held only that a State could not proscribe picketing merely by setting artificial bounds, unreal in the light of modern circumstances, to what constitutes an industrial relationship or a labor dispute." 55

Although some may feel that to be no more than a judicial flourish, the writer thinks it quite candidly states what has moved the Court in Hanke and in the other picketing cases decided from Giboney to date. Metes and bounds, realistic in 1940-1943, are now unrealistic because of intervening circumstances. What circumstances? Congress had brought interstate union activities under the effective control of national legislation in the Taft-Hartley Act, and the Court, in turn, had assured that state law would not upset the congressional balance. As Mr. Justice Frankfurter told us, by 1950 times had changed, even as by 1940 the notions of prior decades had become outmoded.

This fact became more apparent as Mr. Justice Minton read his opinion in the Gazzam case. ${ }^{56}$

"It is the public policy of the State of Washington that employers shall not coerce their employees' choice of representatives for purposes of collective bargaining. Do the First and Fourteenth Amendments to the Federal Constitution permit the State, in reliance on this policy, to enjoin peaceful picketing carried on for the purpose of compelling an employer to sign a contract with a labor union which coerces his employees' choice of bargaining representátive?" 57

The Court answered affirmatively and held Washington could enjoin the union "from endeavoring to compel plaintiff to coerce his employees to join the defendant union or to designate defendant union as their representative for collective bargaining, by picketing the hotel premises of plaintiff. . . ."58 But what about Swing? "In that

54. $I d$. at 471.

55. $I d$. at $479-80$.

56. Building Service Employees Int'1 Union v. Gazzam, 339 U.S. 532 (1950).

57. Id. at 533 .

58. Ibid. 
case," said Mr. Justice Minton, "this Court struck down the State's restraint of picketing based solely on the absence of an employer-employee relationship. . . The State has not here, as in Szving, relied on the absence of an employer-employee relationship." In Gazzam the state relied instead on a nonrelational policy. "An adequate basis for the instant decree is the unlawful objective of the picketing, namely, coercion by the employer of the employees' selection of a bargaining representative." 59 Thus, it may still have been possible to argue that the Court thereby left open the potential of co-existence of the relational policies it had developed in the earlier cases and the nonrelational policies upheld in Giboney, Hughes, Hanke and Gazaam.

The next case, however, squelched whatever speculative doubts may have lingered as to the significance of the earlier cases. In International Brotherhood of Electrical Workers (IBEW) v. NLRB, ${ }^{60}$ the union had picketed construction sites in protest against the use of nonunion subcontractors. Congress the Court said, sought in Section 8(b) (4) (A) of the Taft-Hartley amendments to outlaw the secondary boycott.

“. . . we recently have recognized the constitutional right of states to proscribe picketing in furtherance of comparably unlawful objectives. There is no reason why Congress may not do likewise." 01

This curt dismissal of the first group of post-Thornhill casesbased as they were on a concept of unity of interest which would have protected this particular pressure-was underscored by citation only of Giboney through Gazzam. The IBEW decision confirmed Mr. Justice Frankfurter's Hanke observation that times had changed.

Another secondary pressure situation, though at the state level, was presented in the 1953 Graham case. ${ }^{62}$

"The immediate results of the picketing demonstrated its potential effectiveness, unless enjoined, as a practical means of putting pressure on the general contractor to eliminate from further participation all nonunion men or all subcontractors employing nonunion men on the project." Bs

59. Id. at 539. It has been argued that the Gazzam decision means that the states may virtually eliminate organizational pressure by means of picketing. Gregory, supra note 19, at 203.

60. 341 U.S. 694 (1951) (cited hereinafter as the IBEW decision).

61. Id. at 705 .

62. Local Union No. 10, United Ass'n of Journeymen Plumbers v. Graham, 345 U.S. 192 (1953).

63. Id. at 201. 
Gazzam gave over to the states the picketer who sought to organize reluctant employees by bringing pressure to bear on their employer. The Graham pressure involved an extra, though common step. Seeking to obtain work being performed by nonunion workers, the picketers wanted a general contractor to put pressure, in turn, upon the subcontractors who were hiring nonunion men. This was held violative of the state's "right to work" statute. Both Graham and Gazzam have furthered a tendency toward uniformity on a national scale since Congress, with the Court's approval, has covered both situations with regard to interstate cases. ${ }^{64}$

The first group of post-Thornhill decisions (Swing through $A n$ gelos) were disposed of on a relational basis which is not of decisive significance in the second group (Giboney through Graham). The unity of interest doctrine, a concept of economic interdependence, was the leitmotif of the first group. It does not appear in the second group. Of these latter cases, five of the six were decided on nonrelational grounds. The first (Giboney) involved trade restraint policies, the second (Hughes) racial discrimination, and three of the last four (Hanke, Gazzam, Graham) appear to reflect a current concern for individual freedom in the face of union group pressures which may eventually become more clearly recognizable as a pattern if a counterpoint like Ritter's Cafe becomes available to the Court. Only in the $I B E W$ case was there required of the Court the kind of policy decision on a strict relational basis comparable to the earlier group.

The cases in the first group-Swing, Ritter's Cafe, Wohl, Angelos-suggest the effectiveness of the Court's picking and choosing, affirming and reversing, among state picketing policies. That the Court in the second group-Giboney, Hughes, Hanke, Gazzam, Graham-has had occasion only to affirm state restrictions does not seem to lessen the effect of its national umpirage. Further, although the times have-changed so as to render the first group of cases outdated, it should be noted that despite the obvious inconsistency of the second group of cases with the first group, the Court has not overruled the first group of cases. Indeed, its express basis of distinction in Hanke-modern circumstances-preserves their precedent value in the event that the fortunes of industrial warfare suggest that they again be called up for active duty.

In Gazzam and Graham the Court as umpire allowed states to parallel Congress, as may be seen by its Taft-Hartley decisions in the

64. 61 STAT. 141 (1947), 29 U.S.C. \$158(b) (4) (Supp. 1952). See Garner v. Teamsters Union, 346 U.S. 485 (1953); NLRB v. International Rice Milling Co., 341 U.S. 665 (1951); NLRB v. Denver Bldg. \& Construction Trades Council, 341 U.S. 675 (1951); IBEW v. NLRB, 341 U.S. 694 (1951) ; Local 74, United Brotherhood of Carpenters \& Joiners of America v. NLRB, 341 U.S. 707 (1951). 
Garner ${ }^{65}$ and $I B E W^{68}$ cases. But in Hanke, it allowed the state a more constrictive policy than Congress has yet seen fit to adopt for interstate industries.

This suggests that the Court may not have retreated from any earlier impulsiveness as has so generally been assumed. ${ }^{67}$ It is inferable, from the course of decision at least, that the Justices who voted for Thornhill projected fairly clearly where they might go from that initial landmark. Indeed, the "retreat" which has been deplored or cheered, according to the promptings of conviction, may thus be more apparent than real, a withdrawal from a position hypothecated by its critics rather than established by its decisions. And, as the Court reminds us periodically, it is the decisions that count. ${ }^{68}$

Yet, from the beginning, the Thornhill decision has been summarily dismissed as an egregious blunder. When one reads again the caustic criticism of that "unguarded opinion" ${ }^{60}$ which has been thought to be so laughable to knowing union men, ${ }^{70}$ one wonders who has had the last laugh after all, the hardheaded union men and professors or hardheaded jurists.

Thus, in sum, by its Thornhill decision the Supreme Court took over exclusive control of intrastate as well as interstate labor cases involving picketing. It thereby assumed the power to foreclose state regulation of picketers to whatever degree it might find required by the Justices' view of the economy. The Court as a result has formulated policy as much or more by its negative self-restraint in the face of state regulation as by its positive intervention to make picketing immune to particular restraints. There is always in the background the power under Thornhill to stop particular state encroachments on the utilization of picketing pressures.

As a result, a national pattern of allowability has emerged which appears to reflect the current trend toward increased constriction of union power. It may be that this over-emphasizes the national pat-

65. Garner v. Teamsters Union, 346 U.S. 485 (1953).

66. IBEW v. NLRB, 341 U.S. 694 (1951).

67. See, e.g., Corwin, supra note 4, at 486; Gregory, $A$ Defense, supra note 6, at 1057; Jones, $A$ Jurisprudence of Epithets, supra note 4, at 1033; Smith, supra note 19 , at 27 .

68. See Hughes v. Superior Court of Cal., 339 U.S. 460, 465 (1950) ; International Brotherhood of Teamsters Union v. Hanke, '339 U.S. 470,480 n.6 (1950).

69. Corwin, supra note 4 , at 486.

70. "The writer has heard workingmen laugh aloud at these decisions [Thornhill, Carlson, Wohl] when the ground of the decisions was made clear to them. A reaction more articulate than these laughs, but based upon the same very sensible notions, is - [Gregory, Peaceful Picketing and Freedom of Speech, 26 A.B.A.J. 709 (1940) j." 2 CRosskey, Politics AND The Constitution IN, the History of THE UnIted States 1258 n.36 (1953). See Gregory, $A \cdot$ Defense, supra note 6 , at 1056. 
tern-setting effect of the Court's allowance of state curtailments. But it is generally recognized that states are prone to exercise the full poential of control over labor union activity left to them by Congress or the Court. Be that as it may, the Court is assured flexibility for its consideration of future picketing cases through the approach suggested in Hanke: Has the state set up bounds which are realistic in the light of contemporary economic facts of life? ${ }^{71}$ Its preservation as prec-

71. See text at note 55 supra. In one way or another this statement from Hanke seems to hold the key to the Court's picketing analysis. But it could be that Ar. Justice Frankfurter may have meant something less sweeping in that sentence than is at first apparent. The post-Thornhill unity of interest doctrine was designed at least as much to protect neutrals against unreasonable involvement as to allow unions to pursue their economic self-interest within reasonable bounds. Perhaps even more weight should be given to the former than to the latter. The Court may in those cases have set just the outer limits beyond which unions were always to be vulnerable to picketing injunctions without concern for any policy thereby served other than that which was protective of neutrals in the relational terms of "labor dispute" as construed by the Court. It does not necessarily follow that the Court at the same time set inner limits within which union picketers were never to be vulnerable to injunctions issued to protect other economic or social policies. It may be that the Court assumed that within that relational area where unions were to be immune to regulation based only on industrial realtionships they could still be curbed in deference to other policies not couched in relational terms. May it then be argued that the second group of post-Thornhill cases is therefore consistent with the first? The basic contention would be that, once having corralled the unions to protect neutrals, the Court continued thereafter within that area to curb union power wherever its manifestation by picketing threatened to upset nonrelational policies of legitimate concern to the states and Congress. (The writer is indebted to Professor Allan McCoid for the suggestion of the possibility of this line of reasoning.)

Does this argument stub its appeal, however, on the Hanke and IBEW cases? It may be argued that in the earlier Swing, $W$ ohl, and Angelos cases the Court focused only on the circle-drawing of the state-the area of privileged picketing could not be constricted to the employer-employee relationship; that the presence of the self-employer was simply a point of departure for a relational analysis and was no more determinative of the result than if there had been involved a typical stranger picketing case setting union picketers against nonunion workers and their employer; that, in contrast, in Hanke the Court focused actually upon the social utility of a policy protective of self-employers as such because that was the state policy at issue rather than the relational policy of. the earlier cases. This line of argument finds substantial support in the statement by Mr. Justice Jackson in the Wohl opinion that, "The respondents say that the basis of the decision below was revealed in a subsequent opinion of the Court of Appeals, where it was said with regard to the present case that 'we held that it was an unlawful labor objective to attempt to coerce a peddler employing no employees in his business . . . to hire an employee. : . . But this lacks the deliberateness and formality of a certification, and was uttered in a case where the question of the existence of a right to free speech under the Fourteenth Amendment was neither raised nor considered." Bakery \& Pastry Drivers \& Helpers Local v. Wohl, 315 U.S. 769, 774 (1942). But see Gregory, supra note 19, at 203-4.

Further, Mr. Justice Minton, in distinguishing Swing in the course of his Gazzam opinion, used language which would appear to strengthen this line of reasoning. "Petitioners insist that the' Swing case, supra, is controlling. We think not. In that case this Court struck down the State's restraint of picketing based solely on the absence of an employer-employee relationship. An adequate basis for the instant decree is the unlawful objective of the picketing, namely, coercion by the employer of the employees' selection of a bargaining representative. Peaceful picketing for any lawful purpose is not prohibited by the decree under review. The State has not here, as in Swing, relied on the absence of an employer-employee relationship." Building Service Employees v. Gazzam, 339 U.S. 532, 539 (1950).

But what of $I B E W$ ? There the policy clearly was relational; secondary boycotts, as such, were outlawed. Did sustaining that congressional policy violate the 
edents of its earlier picketing cases-Swing through Angelos-supports this analysis of what the Court has done, and continues to do, in its reaction to the economic consequences of picketing.

This may or may not be sound economic technique. It may or may not be thought to embody a wise theory of governance. But was it not rendered inevitable by the Court's acknowledgment in Thornhill of the freedom of expression issue which is inextricably present in these cases since they involve peaceful persuasion with economic consequences? Examination of the development and application of the "clear and present danger" test in the picketing decisions may suggest the answer to that question.

III.

In sketching the outline of the constitutional right to picket, $\mathrm{Mr}$. Justice Murphy explicitly made applicable to it the "clear and present danger" test spelled out in the speech cases. ${ }^{72}$ The Justices (and their critics) have since been troubled by the right to picket because of an apparent feeling that accommodation to it of this aspect of the reasoning of the free speech cases has not been very satisfactory.

The "clear and present danger" formula is essentially a refinement of the concept of unlawfulness which any society sets against the activities of its citizens individually or in groups. It adds the requisites of imminence and substantiality of adverse consequence to the common good, and at the same time requires that the activity which is deemed undesirable must also involve substantial consequence to the commonweal. Thus, it is said by the Supreme Court that there must be a finding of substantial evil ${ }^{73}$ as well as a finding that the conduct sought to be barred constitutes a "clear and present danger" of effectuating that evil. ${ }^{74}$ The wisdom of that twofold skepticism ${ }^{75}$ suggests

Court's own pre-Taft-Hartley national policy protective of neutrals otherwise embroiled by industrial warfare? It would seem that it did inasmuch as the Court's policy was not antagonistic to secondary boycott as such, but only those which reached beyond the area of unity of economic interest. $C f$. Goldfinger v. Feintuch, 276 N.Y. 281, 11 N.E.2d 307 (1937). That the IBEW decision was inconsistent with the Court's earlier relational cases is indicated further by Mr. Justice Burton's omission of those cases from his citation of authority and inclusion instead of the decisions-Giboney through Gazzam-which might, but for the IBEW decision, be distinguished as indicated in this footnote so as to leave the Court's consistency above reproach. Of course, some doubt that the Court would be fulfilling its constitutional responsibility if it were not periodically inconsistent.

72. Thornhill v. Alabama, 310 U.S. 88, 103-4 (1940). See the detailed discussion in Richardson, Freedom of Expression and the Function of Courts, 65 Harv. L. REv. 1 (1951). But compare Rostow, The Democratic Character of Judicial Review, 66 HaRv. L. Rev. 193 (1952).

73. See Whitney v. California, 274 U.S. 357,372 (1927) (concurring opinion).

74. Schenck v. United States, 249 U.S. 47, 52 (1919).

75. This article does not purport to probe the policy and doctrinal factors of the "clear and present danger" reasoning, as such. It is concerned with it only 
that the Court scrutinize the policy invoked as justification for the repression so as to be assured that, if free expression does thwart that policy, grave harm may result and not mere annoyance. ${ }^{76}$ The other phase of its inquiry raises the question whether or not the particular activity challenged constitutes a "clear and present danger" of effectuating the harm apprehended. ${ }^{77}$

It seems that it would be an unreal simplification to suggest that the Court either does or can (or should) strictly compartmentalize these two phases of its inquiry. It would seem inevitable that the Court would to some degree balance the requisites of evil and danger relatively - the more grave the former, the less pressing need be the latter, and vice versa-in order to attain a satisfactory result in specific circumstances. ${ }^{78}$ Thus, while the evil-danger dichotomy seems to have analytical utility for purposes of clarity, it is hardly to be thought of as a mechanistic contrivance for decision. It is a means for expressing a composite of value preferences. ${ }^{79}$ From them has evolved the prevailing attitude of judicial skepticism of justifications advanced in support of encroachments on freedom of expression. Preferences among notions of residual state power and the proper scope of federal power, ${ }^{80}$ of the relative detachment and competence of the federal and state judiciary, of the proper relation of courts and legislatures in determining policy, ${ }^{81}$ of economic and societal wisdom, of philosophical conceptions of man and society, and more, are involved. Perhaps the most articulated preference reflected by the evil-danger dichotomy is that which adopts a market place rather than a hothouse concept of the discovery and propagation of truth. ${ }^{82}$ It is a belief that ideas which are tested and survive and grow in an atmosphere of freedom will be more reflective of truth and thus more beneficial to humanity than those

so far as is necessary to demonstrate its adaptation to the right to picket. The "test" has already been subjected to detailed and penetrating analysis. See CHAFEE, FrEE Speech in the UnITEd States (1941); Richardson, supra note 72; Rostow, supra note 72.

76. See Abrams v. United States, 250 U.S. 616, 630-31 (1919) (dissenting opinion); Giboney v. Empire Storage \& Ice Co., 336 U..S. 490, 502 (1949).

77. See Richardson, supra note 72, at 6 et seq.

78. Cf. Dennis v. United States, 341 U.S. 494, 510 (1951) ; United States v. Dennis, 183 F.2d 201, 212 (2d Cir. 1950) (per L. Hand, J.).

79. See Pennekamp v. Florida, 328 U.S. 331, 336 (1946) ; FREUND, ON UNDERstanding tee Supreare Court 27 (1949).

80. See Thomas v. Collins, 323 U.S. 516 (1945).

81. See Hamilton and Braden, The Special Competence of the Supreme Court, 50 YALE L.J. 1319 (1941); Richardson, supra note 72, at 43 et seq.; Rostow, supra. note 72 .

82. See Abrams v. United States, 250 U.S. 616, 630 (1919) (dissenting opinion). 
nurtured under the artificially created protection of political favoritism. ${ }^{83}$

The attitude of judicial skepticism of restrictions which is the product of such considerations as these seems well nigh impossible of reduction to the compass of doctrine other than in terms of an abiding caution in the accommodation of particular interests competing under particular facts in particular cases. ${ }^{84}$ If this be a realistic statement of the "clear and present danger" test in action, it would seem that in criticizing the cases we should look more for that caution than for strict analogue. That at least is the basic critical assumption which underlies the analysis to which we now turn. The Court's adaptation of the "clear and present danger" reasoning to the right to picket will be examined, first, in terms of the element of substantial evil and, second, in terms of the element of clear and present danger.

\section{The Element of Substantiality}

Our examination of the picketing cases as economic documents suggests that the substantial evil element of the "clear and present danger" test, as it has been applied to labor picketing, may be phrased in terms of the question suggested by Mr. Justice Frankfurter in Hanke: Has the state set up bounds which are realistic in the light of contemporary economic circumstances?

Since the necessity of decision requires the Court to make basic policy adjustments in our economy, and since it must make them not on the narrow ground of economics but with a view of all the social disciplines helpful to governance, it seems unrealistic to say that the Justices are thereby arrogating unto themselves policy decisions belonging to the legislatures. ${ }^{85}$

The Court has been explicit in recent picketing opinions, however, in abjuring any intent to rule on the "wisdom" of the particular policy

83. See, e.g., the much quoted Mirton, Areopagirica 51-52 (Hales ed. 1917). See also L. Hand, J., in United States v. Associated Press, 52 F. Supp. 362, 372 (S.D.N.Y. 1943) : “. . the interest protected by the First Amendment... presupposes that right conclusions are more likely to be gathered out of a multitude of tongues, than through any kind of authoritative selection. To many this is, and always will be, folly; but we have staked upon it our all."

84. See Dennis v. United States, 341 U.S. 494, 524, 525 (1951) (concurring opinion).

85. "Sooner or later the conflicts in the economic and social world result in litigation before the Court. De Tocqueville, in 1832, . . . had the discernment to see what later writers have so often not seen that by the very nature of our Constitution practically every political question eventually, with us, turns into a judicial question. The question may become somewhat mutilated in the process, but come before the Court it will." Frankfurter, Chief Justices I Have Knowen, 39 VA. L. Rev. 883, 895 (1953). A picturesque expression of this idea had appeared many years earlier in England. " $[F]$ or the sparks of all the sciences in the world are raked up in the ashes of the law." FINCH, A DEscription of THE Common LAw, quoted in Doolan, ORDER AND LAW xvii (1954). 
adduced in support of a ban on expression. Mr. Justice Minton stated it typically in the Gazzam opinion:

"To judge the wisdom of such policy is not for us; ours is but to determine whether a restraint of picketing in reliance on the policy is an unwarranted encroachment upon rights protected from state abridgment by the Fourteenth Amendment." 86

But when may it be said that a restraint is "unwarranted"? How can the Court decide if a policy comprehends a "substantial" evil if it does not, to some extent at least, "judge the wisdom of such policy"? The Court has said that it does not suffice that just any sort of policy conception be discerned behind the restraint. More is required of the policy makers. Their policy must comprehend a "substantive evil of such magnitude as to mark a limit to the right of free speech"; ${ }^{87}$ it must not be "an effort to outlaw only a slight public inconvenience or annoyance." 88 Can a distinction be maintained in practice which proposes that the Court need not agree that the evil apprehended by the regulation is a sound policy conception, but need only rule on whether the conception is reasonable? Can the Justices actually break down the complex of value judgments involved in a case so as to isolate and render impotent preferences stimulated by views of the wisdom of the policy? It should be clear enough that deciding not to decide on the wisdom of the policy is every bit as decisive, but a good deal less informed. Further, refusal to judge the wisdom of a policy would narrow the scope of the "clear and present danger" skepticism as a practical matter by eliminating substantiality as an element. Unless the Justices are simply to blindfold themselves to reality in some such manner, they may overlook but they cannot avoid the fact of value judgments which assess the wisdom of the policy and are expressed in terms of a decision on the issue of substantiality.

But it will be observed by some that there is usually a "middle ground" where wise men may differ on the advisability or applicability of a given policy, and that the Court should not superimpose its own choice upon the states or Congress in such circumstances. The vital question, however, is: Whose plat will determine the boundary lines of that middle ground? Obviously, the Court's. And so we are back to the necessity of choice. But there is more to it than that.

\footnotetext{
(1942).

87. Bakery \& Pastry Drivers \& Helpers Local v. Wohl, 315 U.S. 769, 775
} (1950).

86. Building Service Employees Int'1 Union v. Gazzam, 339 U.S. 532, 539

88. Giboney v. Empire Storage \& Ice Co., 336 U.S. 490, 502 (1949). 
It would be quite unrealistic to believe that the judicial abnegation which we are analyzing is no more than a verbal concoction. The picketing cases do indicate, it is true, that the Court has not appeared to be so inhibited in decision when it has felt the state policy to be unwise. $^{89}$ Therefore, it may be that this abnegation insulates the state's wisdom, but it does not appear to protect its unwisdom. What could be irony, however, is a description of a judgmatic fact, a felt restraint on the part of the Justices. Thus, a decision by the Court that a given policy is within the insulated area of that middle ground may mean that the Court is satisfied, perhaps, not so much of the presence of wisdom as of the absence of unwisdom. There is a difference, however subtle, and it is an important one because it involves the indefinable and variable degree of judicial restraint exercised by the Justices as they weigh the policy formulation before them. It would seem that that middle ground of judicial forebearance would expand or shrink in area, would be more or less accommodative of state or congressional policy, according to whether a Justice addressed the issue of substantiality mindful of rejecting unwisdom or intent upon assuring wisdom. The former meaning may fairly be ascribed to the "not for us" statements in the Court's picketing opinions, and they are then a sensible and realistic commentary. If it were otherwise, they would be absurd.

Thus far, the Court has not allowed states to enjoin peacefully conducted picketing where it has found that the state policy sought to limit labor picketing (1) to a dispute between an employer and his employees; ${ }^{00}(2)$ to cases involving a "labor dispute" as defined by state statutes; ${ }^{91}$ or (3) so as to insulate a self-employer against union organizational pressure. $^{92}$ These are the decisions which, with the counterpoint of Ritter's Cafe, ${ }^{93}$ established the unity of economic interest doctrine as a measure of allowable State policy. After these decisions, on the theoretical level at least, there was a national pattern of allowability of picketing pressure which was geared to "labor dispute" concepts. These cases seem to embrace within the concept of substantial evil any attempts to embroil in the economic pressures generated by the picket line members of the general community- "neutrals"-outside the area of economic interdependence in which the dispute arose.

89. See AFL v. Swing, 312 U.S. 321 (1941); Bakery \& Pastry Drivers \& Helpers Local v. Woh1, 315 U.S. 769 (1942); Cafeteria Employees Union v. Angelos, 320 U.S. 293 (1943).

90. AFL v. Swing, 312 U.S. 321 (1941).

91. Bakery \& Pastry Drivers \& Helpers Local v. Wohl, 315 U.S. 769 (1942).

92. Cafeteria Employees Union v. Angelos, 320 U.S. 293 (1943).

93. Carpenters \& Joiners Union of Am. v. Ritter's Cafe, 315 U.S. 722 (1942). 
It wasn't until 1949 that an occasion arose in which the Court was called upon to uphold a state policy expressed in other than the relational terms of a "labor dispute." A series of five decisions have come down since then, however, in which the Court has allowed peacefully conducted picketing to be enjoined in circumstances where the state ${ }^{04}$ policy at issue was expressed in terms of (1) a conventional trade restraint statute; ${ }^{05}$ (2) judicial rejection of discriminatory racial picketing; ${ }^{96}$ (3) judicial insulation of a self-employer against the union organizational pressure of picketing; ${ }^{97}(4)$ and (5) statutes insulating freedom of association or nonassociation of individual workers against employer interference. ${ }^{88}$ Of these five, the last three cases appear to reflect concern for the freedom of the individual who is subjected to group economic pressures. Of course, it is quite clear from these decisions that the Court has, for now at least, deserted the relational policies it formulated through the earlier cases. Should the Court ever feel the need to revert to them, it need merely invoke Mr. Justice Frankfurter's Hanke ${ }^{99}$ formula. ${ }^{100}$

94. IBEW v. NLRB, 341 U.S. 694 (1951), concerned the Labor-Management Relations Act bar on secondary boycotts, 61 STAT. 141 (1947), 29 U.S.C. $\S 158$ (b) (4) (A) (Supp. 1951).

95. Giboney v. Empire Storage \& Ice Co., 336 U.S. 490 (1949). See AnnheuserBusch, Inc. v. Weber, 33 Lab. Ret. Rep. 2519 (Mo. Sup. Ct. 1954) (anti-trade restraint policy invoked, citing Giboney, where picketing to force employer to agree to grant subcontracts only to employers organized by picketing union).

96. Hughes v. Superior Court of Cal., 339 U.S. 460 (1950). (1950)

97. International Brotherhood of Teamsters Union v. Hanke, 339 U.S. 470

98. Local Union No. 10, United Ass'n of Journeymen Plumbers v. Graham, 345 U.S. 192 (1953) ; Building Service Employees Int'l Union v. Gazzam, 339 U.S. 532 (1950).

99. The Hanke decision seems clear enough, but the opinion as a whole is somewhat difficult to assimilate. Indeed, the case reminds one of Chesterton's little friend who said to her mother, "I think I should understand if only you wouldn't explain." Recently, Mr. Justice Frankfurter has given us an engaging sketch in which we may incidentally glimpse the germinative potential of such expressions as appeared in the course of the Hanke opinion. See Frankfurter, supra note 85, at 904. If picketing is a "hybrid," as he tells us in the Hanke opinion, one gets the distinct impression that it is a unique variety he has set to seed. International Brotherhood of Teamsters v. Hanke, 339 U.S. 470, 474 (1950).

An interesting and noteworthy aspect of the post-Thornhill cases is $\mathrm{Mr}$. Justice Frankfurter's apparent fixation on the Senn case. One almost gets the feeling that he is pointing for a sub silentio overruling of Thornhill and reinstatement of Senn. It seems, however, to be a matter of either/or; presumably the Court cannot at the same time maintain two valid precedents, one saying the Constitution does not prevent a state allowing or prohibiting picketing as it chooses (Sennt), the other saying the Constitution does prevent a state allowing or prohibiting picketing as it chooses (Thornhill). But the Justice is apparently loath to commit Semin to the constitutional historians. Indeed, he persists in applying artificial respiration when hope should decently surrender.

In his second post-Thornhill opinion he quoted as authority the outmoded and ambiguous Brandeis dictum: "Members of a union might, without special statutory authorization by a State, make known the facts of a labor dispute, for freedom of speech is guaranteed by the Federal Constitution. Senn v. Tile Layers Union, 301 U.S. 468, 478." AFL v. Swing, 312 U.S. 321, 326 (1941). See Gregory, supra note 19, at 199. In the Angelos case, he again quoted that dictum, now as a rule, and, indeed, hinged the post-Thornhill cases on Semn rather than Thornhill: "Later 
Insofar as the issue of substantiality is concerned, then, it is hard to see these decisions as flouting any reasonable concept of caution deducible from the "clear and present danger" reasoning previously analyzed. They were not simply ruses for whittling union power or for banning appeals for public support of union causes. Nor do any of them appear to reflect undue sensitivity to unwelcome or controversial opinions. All involved matters of serious concern to the states. Yet these decisions have been taken as having opened a Pandora's box of repressive state policies. Thus, for example, it is said:

cases applied the Semn doctrine by enforcing the right of workers to state their case and to appeal for public support in an orderly and peaceful manner regardless of the area of immunity as defined by state policy. A.F. of L. v. Sreving, 312 U.S. 321 ; Bakery Drivers Local v. Wohl, 315 U.S. 769. To be sure, the Senn case related to the employment of 'peaceful picketing and truthful publicity.' 301 U.S. at 482." Cafeteria Employees Union v. Angelos, 320 U.S. 293, 295 (1943). Then in the Hanke case came an express avowal of state power utterly inconsistent with the Thornhill precedent but quite consistent with the Senn decision:

"Here we have a glaring instance of the interplay of competing social-economic interests and viewpoints. ...

"Whether to prefer the union or a self-employer in such a situation, or to seek partial recognition of both interests, and, if so, by what means to secure such accommodation, obviously presents to a State serious problems. . . . That the solution of these perplexities is a challange to wisdom and not a command of the Constitution is the significance of Sem v. Tile Layers Protectize Union... - In rejecting the claim that the restriction upon Senn's freedom was a denial of his liberty under the Fourteenth Amendment, this Court held that it lay in the domain of policy for Wisconsin to permit the picketing: "Whether it was wise for the State to permit the unions to do so is a question of its public policy-not our concern.' 301 U.S. at 481.

"This conclusion was based on the Court's recognition that it was Wisconsin, not the Fourteenth Amendment, which put such picketing as a 'means of publicity on a par with advertisements in the press.' 301 U.S. at 479 . If Wisconsin could permit such picketing as a matter of policy it must have been equally free as a matter of policy to choose not to permit it and therefore not to "put this means of publicity on a par with advertisements in the press.' If Wisconsin could have deemed it wise to withdraw from the union the permission which this Court found outside the ban of the Fourteenth Amendment, such action by Washington cannot be inside that ban." International Brotherhood of Teamsters Union v. Hanke, supra at 475-7.

These attentions to Senn have been accompanied by corresponding snubs of Thornhill in the opinions. Thus, you will find the "Senn doctrine" in the Angelos opinion but you will not even see Thornhill cited there; and in Hanke, Thornhill barely gets a perfunctory nod before the Justice gets down to work on Senn again. This somewhat novel form of artificial respiration may revive Senn, but it will surely be fatal to Thornhill.

It was indeed Wisconsin that allowed picketing in 1937. Also, that state in 1937, as the Justice notes, could as readily have barred picketing. But Alabama couldn't when it tried in 1940, and that is the crux. "The starting point is Thornhill's case," said the Justice before his attempt to revive Senn became evident. Milk Wagon Drivers Union of Chicago v. Meadowmoor Dairies, Inc., 312 U.S. 287, 293 (1941). He might better have said that Thormhill's case was the turning point. In fact, it was an about-face.

This seems like a devious way of achieving what the Court can do just as well and with much more becoming candor simply by accepting Thornhill $v$. Alabama as its "starting point" and letting the Serm case descend respectfully into historical footnotes. Surely, Mr. Justice Brandeis would have been the last to object to such a requiem.

100. "In those cases, we held only that a state [or Congress] could not proscribe picketing merely by setting artificial bounds, unreal in the light of modern circumstances. . " International Brotherhood of Teamsters Union v. Hanke, 339 U.S. $470,479-80$ (1950). 
"Certainly if the states are allowed to stop picketing indirectly, by making its objectives unlawful for tradesmen, then they should be able to do it by placing restrictions directly on unions. . . . Quite inevitably, the Thornhill doctrine is being pushed back to its only logical application-a sanction against blanket prohibitions aimed at all peaceful picketing. There it will remain a monument to the Court's 'good will,' causing little trouble to state and federal legislatures who know what they want." 101

No doubt it is possible to use the second group of decisions inductively to construct syllogisms which might appear to demolish the constitutional right to picket or at least so drastically crimp it as to limit its effectiveness to a sanction against blanket prohibitions. But that kind of "logical application" seems to be precisely the type of misapplication of logical principles to data which has given syllogistic reasoning a bad name. While it is true that the Court could construct a logical framework which would all but efface Thornhill, the question whether it will do so is not to be answered in terms of logical potential but, again, in Mr. Justice Frankfurter's words, "in the light of modern circumstances."

A dogmatic conclusion of the Court's present attitude toward the allowable scope of state policy is impossible. But it may at least be said that analysis of the picketing decisions as instruments of contemporary economic policy supports an inference that the Court may or may not have loosened but it certainly has not dropped the reins curbing state labor regulation in terms of picketing. It seems premature to say that Thornhill has been cast aside; the writer believes it would prove to be costly error for legislators, judges, or employers formulating labor relations policy to assume that the Court will now brook almost any restriction of picketing which local temper dictates. Of ' course, the Court would cut the limb behind me by overruling Thornhill, but it seems more likely that it will continue to utilize the umpirage that precedent affords rather than lop it off. After all, why should it overrule Thornhill? State regulation has certainly not been rendered impotent by the "clear and present danger" reasoning which Thornhill's existence assures. And the Court has a good deal more flexibility in solving difficult labor law problems with it than it would without it.

But-does the foregoing reasoning leave Thornhill as a hollow. "monument to the Court's 'good will' toward freedom of expression"? On the contrary. It will become apparent, however, that it is in the other phase of the "clear and present danger" test-probing the actual danger to the state's policy of the particular activity challenged-that

101. Gregory, supra note 19, at 204, 205. See id. at 203. 
the vitality and importance of Thornhill is to be found. Contemporary economic and political realities are such that the Court's picketing cases are not so apt to be resolved on the basis of justifiability of state policy. Recent cases indicate that the decisions may turn instead on whether the Court gives close or casual attention to the connective element of actual danger- "clear and present"-linking the particular activity enjoined to the particular policy to be protected.

\section{The Element of Danger}

Close attention to the other element of the "clear and present danger" test requires that the Court be satisfied both of primary and of ultimate effectiveness. This means that it should have been demonstrated for the Court that the expression challenged can and will, unless enjoined, both gain the concurrence of others and, in turn, thereby endanger the policy to be protected.

The usual picketing case differs from the usual speech case in this regard. Almost invariably, at least in those cases which reach the appellate courts, effectiveness of the picketers' appeal for concurrence has been demonstrated. Objective data are readily procurable. Percentages of profits lost, or of workers quitting projects, for example, afford the courts reliable evidence of the impact of the picket line. For "clear and present danger" purposes, however, such evidence should not complete the case. It sets up proof only of primary effectiveness. It shows that the picketing is effective in that viewers have responded favorably to the picketers in significant numbers. But significant of what? That question must be answered through another. Is this primary effectiveness likely to result in the ultimate violation of the preferred policy? The cases indicate that these two stages of effectiveness should be carefully differentiated. Whether the picketing challenged has been primarily effective in gaining concurrence, and, if so, whether there is a real threat that it will also be ultimately effective against the policy, are separate questions of fact to be resolved in the circumstances of each case. The caution formalized by the "clear and present danger" test imposes upon the Court the responsibility of insisting that both facets of effectiveness be proven to exist. Thus, primary effectiveness alone does not justify barring picketing. The effect on the viewers must, in turn, be found to endanger maintenance of the policy.

Mr. Justice Douglas in his Wohl concurring opinion made an observation which highlights this phase of our analysis.

"If the opinion in this case [Wohl] means that a State can prohibit picketing when it is effective but may not prohibit it 
when it is ineffective, then I think we have made a basic departure from Thornhill v. Alabama. . . ." 102

If we assume that the Court has already decided the issue of substantiality in favor of the state's policy, it would appear that prohibition of effective and protection of ineffective picketing is exactly what the Court did mean in Thornhill (policy frustration), if what we are talking about is ultimate effectiveness. On the other hand, if it is to primary effectiveness (viewer concurrence) that the Justice refers, prohibition would be a departure from Thornhill unless the primary effect of viewer concurrence were linked causally to the ultimate and forbidden effect of policy frustration.

An examination of Giboney, Gazaam, and Graham will point up these distinctions.

In Giboney, the Court accepted the state definition of unlawful activity: a compact between a wholesaler and union retailers exclusive of nonunion retailers. This met the necessity for a serious substantive evil under the "clear and present danger" test. The Court concluded that the picketing should be regarded as clearly and presently in danger of effectuating that evil because the picketing had the assurance of success in that regard. It was initially effective. There was an 85 percent reduction in business. It seems clear that the primary effectiveness would have driven the company to do just what would violate the statute: sign the agreement. The state was able to control an instance of peacefully conducted picketing because the Court allowed it to only after inquiry into the nature and the gravity to the state of the effect of the activity forestalled by the injunction. The Court found that the state's "enforcement of its antitrust laws cannot be classified as an effort to outlaw only a slight public inconvenience or annoyance." ${ }^{103}$ It then found the requisite causal connection between the primary effectiveness of the picketing and the policy the state sought to preserve. "There was clear danger, imminent and immediate, that unless restrained, appellants would succeed in making that policy a dead letter insofar as purchases by nonunion men were concerned." 104

From the moment of its conception, the Thornhill doctrine carried the seed of Giboney ${ }^{105}$ simply because the latter represents no more than a careful application of the "clear and present danger" test. The vigor of the constitutional right to picket will not be sapped so

102. Bakery \& Pastry Drivers \& Helpers Local v. Wohl, 315 U.S. 769, 775 (1942) (concurring opinion).

103. Giboney v.. Empire Storage \& Ice Co., 336 U.S. 490, 502 (1949).

104. Id. at 503.

105. But see Gregory, supra note 19 , at 201. 
long as the Court is cautious in applying that test. The degree of caution exemplified by Giboney requires, first, that the "evil" foreseen, the bad effects produced by picketing interdicting a good policy, be substantial and not fanciful; second, that the picketing be primarily effective (viewer concurrence) ; and third, that the primary effectiveness be so proximately linked to the effectuation of the "evil" that allowance of the activity raises an "imminent and immediate" threat of nullifying the policy (ultimate effectiveness).

Was Gazzam decided in accordance with these principles deducible from Thornhill and Giboney? It is not at all clear whether the picketing had resulted in a decrease in the Inn's business, merely "embarrassed" it, or had no effect whatsoever upon it. This goes to the issue of primary effectiveness. The Washington Supreme Court indicated only that:

"Shortly after the picketing started, a laundry which had cared for appellant's needs, and whose employees belonged to the union, refused to work for appellant. Appellant then attempted without success to do his own laundry." 100

There is no indication whether or not other laundry service was in fact available to the Inn, nor, for that matter, whether the refusal of the laundry was actually attributable to the picket line or to knowledge of the dispute gained by other means or for reasons unconnected with the dispute. Yet without factual demonstration of primary effectiveness how can the Court appraise the activity, even cursorily, let alone with the caution embodied in the "clear and present danger" test?

Note that the statutory policy cited by the state court sought to preserve "the individual unorganized worker . . . free from interference, restraint, or coercion of employers of labor. . . ." 107 This statute which the Washington Court relied upon in these terms did not outlaw the inducing of an employer. ${ }^{108}$ It adopted an intermediate position. It sought to preserve the worker free from the fact of restraint. It would seem, therefore, that the picketing would have to pose an "imminent and immediate" threat of effectuating that prohibited restraint before being enjoined.

It is somewhat difficult, however, to picture Mr. Gazzam knuckling under to any but the most serious economic pressure, of a degree,

106. Gazzam v. Building Service Employees, 29 Wash. 2d 488, 490, 188 P.2d 97, 98 (1947), aff'd, 339 U.S. 532 (1950).

107. $I d$. at $491,492,188$ P.2d at 99 .

108. But compare Labor-Management Relations Act, 61 Stat. 141 (1947), 29 U.S.C. $\$ 158(B)(2)$ (Supp. 1952). 
say, that afflicted the ice company in Giboney. ${ }^{100}$ From Mr. Justice Minton's opinion emerges the picture of a determined employer, stubbornly adhering to what he sees as a point of principle, setting a steadfast course from the outset in resisting union overtures.

May it.be said that in Gazzam, the picketer, the picketed employer, and the employees were so linked in circumstances that this picket line actually threatened to touch off a cause-and-effect reaction which would probably result in an effort by this employer to interfere with these employees in their choice between union or nonunion? Although that is the imminence which is requisite under the Court's "clear and present danger" test, it is not present in the facts related in the opinions of either court.

In any event, Gazzam seems to reflect to a serious degree a lack of caution in determining the existence of "clear and present danger." It appears to be incompatible with the Thornhill doctrine, not because of any doctrinal clash, but because of the default involved in too casual a concern for the presence of primary effectiveness connecting the policy favored to the activity, enjoined.

In Graham, on the other hand, primary effectiveness was apparently established. Criticism of the Court's handling of the issue of danger turns instead upon the ultimate effect of the picket line on Virginia's, open shop policy. Mr. Justice Burton spoke for the Court:

"Petitioners here engaged in more than the mere publication of the fact that the job was not $100 \%$ union. Their picketing was done at such a place [at the immediate nexus ${ }^{110}$ of the dispute] and in such a manner ["peaceful in appearance. . . no violence and no use of abusive language." 111 ] that, coupled with established union policies and traditions, ${ }^{112}$ it caused the union men to stop

109. ". . . the picketing had an instantaneous adverse effect on Empire's business. It was reduced $85 \%$. In this dilemma, Empire was faced with three alternatives: It could continue to sell ice to nonunion peddlers, in which event it would be compelled to wage a fight for survival against overwhelming odds; it could stop selling ice to nonunion peddlers thereby relieving itself from further conflict with the union, in which event it would be subject to prosecution for crime and suits for triple damages; it could invoke the protection of the law. The last alternative was adopted.

"Appeliants' power with that of their allies was irresistible." Giboney v. Empire Storage \& Ice Co., 336 U.S. 490, 493, 503 (1949).

110. See Carpenters \& Joiners Union of Am. Ritter's Cafe, 315 U.S. 722 (1942).

111. See Local Union No. 10, United Ass'n of Journeymen Plumbers v. Graham, 345 U.S. 192, 199 (1953).

112. See Richman Bros. Co. v. Amalgamated Clothing Workers of Am., 116 N.E.2d 60 (Ohio 1953), in which the court imposed an injunction on the union's nationwide picketing activities on the stated assumption that a "conspiracy" exists among unions not to cross each others lines. Accord: Winkelman v. Teamsters Union, 31 LAB. REL. Rep. 2016 (Mich. Cir. Ct. 1952) ("social electric eye detonating the social atomic bomb of the universal agreement not to cross the Union's picket line, wherever that picket line may be"). See Jones, $A$ Jurisprudence of Epithets, supra note 4 , at 1044 n.88. 
work and thus slow the project to a general standstill. . . . The immediate results of the picketing [the union men left the project] demonstrated its potential effectiveness, unless enjoined, as a practical means of putting pressure on the general contractor to eliminate from further participation all nonunion men or all subcontractors employing nonunion men on the project." 113

Primary effectiveness was indeed demonstrated by the fact that union men quit the project. But to justify an injunction does it suffice to show only "immediate results" which indicate "potential effectiveness"? That hardly sounds like "clear and present danger" reasoning! Cause and effect certainly don't have to march in locked step across the record in order to establish danger, but "potential effectiveness" seems far removed indeed from the Giboney requirement of "clear danger, imminent and immediate, that unless restrained [the picketers] would succeed in making that policy a dead letter." 114

It is difficult to read Mr. Justice Burton's account of what happened once the picketing started and come away with a feeling of urgent concern that the state's policy against compulsory unionism is about to be violated.

"It is undisputed that the picketing lasted from 8 a.m., September 25 , until stopped by injunction the following noon. . . . The premises picketed were frequented by few except the construction workers. The project was in its earliest stages. . . . Two union ironworkers or rodmen . . . never returned and the contractor was delayed several days while seeking to replace them. A nonunion plumber was assisted by a helper, who, oddly enough, belonged to a printers union. The plumber did not stop work but his helper left when the picketing began.

"The others present were six or seven laborers whose status as union men was not clear. They did not quit but the work on the project as a whole came to a substantial standstill during the week of September 25, because the principal activity then called for was that of pouring concrete which required the services of rodmen as well as those of laborers." 115

This rather casual scene seems to imply little more than a preliminary skirmish. For one thing, how do we know that the contractor could not readily replace the union men? Surely, a trial court's finding of fact based on testimony should be required on that possibility

113. Local Union No. 10, United Ass'n of Journeymen Plumbers v. Graham, 345 U.S. 192, 200, 201 (1953).

114. Giboney v. Empire Storage \& Ice Co., 336 U.S. 490, 503 (1949).

115. Local Union No. 10, United Ass'n of Journeymen Plumbers v. Graham, 345 U.S. 192, 199, 200 (1953). 
under circumstances such as these before it can be concluded with any assurance that the contractor would either be tempted or forced to resort to an unlawful agreement. A couple of rodmen left because of the picketing and "the contractor was delayed several days while seeking to replace them." Here is a project in its earliest stages, some union men leave, it takes several days to replace them, but, we may infer, they are then replaced. Assuming that these facts are enough to constitute a case of primary effectiveness on the ground that union men left the project in response to the picketing, it does not seem there is very much of a threat evidenced thus far at least that the picketing will be ultimately effective, that this contractor in Richmond, Virginia, will be pressured by this picketing into actions violative of the state's open shop policy. Yet these are the considerations which should concern the Court. Speaking for the Court, Mr. Justice Burton said that there was present a "potential" of effectiveness. Yet any appeal for concurrence has such a potential. The question of its control is indeed raised because of that potential; but it can hardly be said to be answered by it.

The foregoing analysis is based on the objective nature of the "clear and present danger" reasoning by which, in a given case, having appraised the issue of substantiality, the Court seeks only to determine if in fact the approved policy is endangered. That kind of determination may be undertaken with reasonable assuredness of objectivity. It is susceptible of factual demonstration. But in the course of his opinion, Mr. Justice Burton asked a different kind of question, $i$. e., whether there is a reasonable basis in the evidence for the finding by the state court that the "conduct and circumstances occurring before and during the picketing . . . demonstrated a purpose . . that was in conflict with the Right to Work Statute." 116 This is not the kind of inquiry which lends itself to objectivity. The intent of the picketer ought not to be deemed relevant to a determination of whether his activity impinges upon state policy. ${ }^{117}$ We have already seen that such comparative figures as those reflecting the impact of the picket line on the employer's balance sheet are readily available.

It is hard to see that the state of the picketer's mind, as long as the picketing is peaceful, has any evidentiary value in deciding if his activity is a danger to the policy to be protected. In addition to its essential irrelevance to the issue, what is now accepted as ancient history in this field indicates without doubt that such "purpose" searching has in the past led courts far afield. What is in the head of the picketer

116. Local Union No. 10, United Ass'n of Journeymen Plumbers v. Graham, 345 U.S. 192, 197 (1953) (italics added).

117. See Richardson, supra note 72 , at 13 et seq. 
tends not to be nearly so important as what is in the head of the trier of facts. It may be that this "purpose" terminology is actually expressive of no more than the Court's concern for the existence of objectively demonstrable facts. We may hope at least that it is not suggestive of that kind of state-of-mind inquiry which actually involves subjective reactions to much more than factual connection of this activity to that policy.

But the Graham opinions are hardly reassuring in this regard. Those opinions, majority and dissenting, afford a good example of the briar patch into which "purpose" searching can lead the Court. In all fairness, it should be added that it was led into it by the trial court's decree which framed the state's policy in subjective terms of intent:

"[I]t appearing to the Court that the picketing complained of was conducted . . . for aims, purposes and objectives in conflict with the . . . laws of the State of Virginia and, therefore, illegal, .. . a permanent injunction is necessary. . . "118

But we may regret that the Supreme Court did not refuse to enter into subjective conceptions of illegality based on "aims, purposes and objectives." It might have insisted instead upon the objectivity of its "clear and present danger" reasoning as a measure of the state's injunction: did this picketing in fact threaten that policy? The welfare of the state would thereby have been amply protected and the right to picket preserved against premature injunction.

In any event, "purpose" searching went on apace. The union official testified that the purpose of the picketing was to inform union men that nonunion men were on the job. The contractor said no, the purpose of the union was to get a "100\% union" job. The trial court then held that the picketing was for "purposes" in conflict with Virginia statutes. Both purposes? Or just one? But, in the latter event, which one? That asserted by the union official or that by the contractor? The trial court did not say. Mr. Justice Burton declared, however, that "the effect of the picketing was confirmatory of its purpose as found by the trial court." But which purpose? If only one purpose were deducible, there would be some point in saying the activity confirmed the intent. But it isn't very enlightening when we don't know which of two purposes is confirmed. The trial court did use the plural, "purposes," so I suppose it could be argued that both were illegal. But

118. Local Union No. 10, United Ass'n of Journeymen Plumbers v. Graham, 345 U.S. 192, 195 (1953). 
in his dissent, Mr. Justice Douglas set it out that a "purpose to deprive nonunion men of employment would make the picketing unlawful," whereas "a purpose to keep union men away from the job would give the picketing constitutional protection." 119 Yet may it not be asked if the two purposes are not in reality one? Isn't the purpose ("unlawful") to deprive nonunion men of employment the purpose which prompts the purpose ("lawful") to keep union men away from the job?

Unfortunately, "purpose" searching doesn't prove very purposeful. Semantics aside, the fact is that the state sought to preserve the worker's freedom of association; the fact is that the Court felt it was legitimate to protect that policy against this form of expression; the fact is that it should not make any difference under "clear and present danger" reasoning which purpose moved the picketers if actually they threatened seriously to frustrate that policy.

Does not this analysis suggest that the practical administration of labor law would be furthered by an objective rather than a subjective test of allowability of picketing? This the Court appeared to recognize in Giboney, and it seems that it would be well advised to return to the surer ground of analysis indicated there. Inquiry would then be concerned with the following factors: (1) is avoidance of the supposed evil (the effects to be anticipated from frustrating the policy) of real consequence to the state's welfare? (2) if so, does this particular picketing in fact threaten to effectuate it? In addition, it would seem helpful if that second question were to be explored in terms of primary and ultimate effectiveness.

Both Gazzam and Graham are unfortunate decisions. It is hard to say that the Court observed the caution required of it by its "clear and present danger" formula in linking the primary effectiveness of the enjoined picketing to frustration of Washington's freedom-ofchoice or Virginia's open-shop policy. Further, it allowed itselfunnecessarily, it would seem-to become entangled in fruitless "purpose" searching. In view of these points of weakness in the Court's analysis, we may hope that in a like situation the Court might (1) reject both the state's injunction and its policy formulation in terms of "purpose"; and (2) in doing so, make explicit its requirement of objective demonstration of effectiveness. Its answer necessarily will be based on its view of proximity in the individual case. But that answer, as the Justices would undoubtedly wish, might then be more realistic and would certainly be less subjective.

119. Id. at 202 . 
IV.

It is impossible to know if the Court has adopted as its shortrange policy a laissez faire policy toward the state's efforts to regulate picketing. In any event, such a policy will be responsive to the facts of each case because the only long-range policy the Court can afford in this sensitive area of economic regulation was expressed in Thornhill. It amounts to no more than the abiding caution of the "clear and present danger" concepts. But these are not to be thought insubstantial. So long as the Court is careful in applying them, they assure both a sound base for protection against intemperate or overly zealous attempts at control and an assurance of an effective area of legitimate state and congressional regulatory freedom.

This, then, is a fluid area of policy formulation which will not be contained by doctrinaire concepts. The one firm principle which need not fluctuate is that this facet of freedom of expression should be accorded the caution of its constitutional status. That caution entails careful application of the evil-danger analysis to the facts of the particular case. While there is flexibility in the contemporary conception of what constitutes substantial evil, the Court should be unyielding in the rigor of its requirement that the connective element of danger be factually demonstrated and not allowed to be subverted by "spurious findings of fact in a State Court." 120

In conclusion, therefore, the writer submits the following propositions as essential to a balanced picketing analysis consonant with the practical administration of our labor laws:

First, constitutional protection of picketing as a right of expression is a proper recognition of the essence of that activity, which is, the communication of ideas in an appeal to viewers for concurrence.

Second, constitutional protection does not, however, render picketing immune to reasonable regulation in terms of peaceful means and lawful ends. Economic consequences attendant upon a successful picket line, which do not alter its essential nature as protected expression, do constitute factors which must be considered in determining what regulation of picketing is to be deemed reasonable.

Third, policy formulations advanced in justification of picketing injunctions should be required to reflect a substantial public interest.

Fourth, preference of such a policy over a claim of constitutional privilege should result (1) only after the picketing challenged has been

120. Milk Wagon Drivers Union of Chicago v. Meadowmoor Dairies, Inc., 312 U.S. 287,299 (1941). 
demonstrated to have primary effectiveness, and (2) only if that effectiveness has also been shown further to be so causally linked to the specific policy as to indicate that coexistence of this picketing and that policy cannot reasonably be expected.

Fifth, in weighing lawfulness of purpose, the Court should avoid a test of legality which is based on the intent of the picketer. The unwholesome kind of hairsplitting and unreal distinction suggested by the Graham opinions is inevitable if the basis be accepted that lawfulness depends on what the picketer thinks rather than on what he does. Whether the particular policy accepted by the Court is seriously threatened by the conduct of the picketer is an objectively measurable fact; it also comprehends what is legitimately objectionable to the state or to Congress. The practical administration of our labor law, as well as general respect for it, would be well served by the Court if it does in this regard what it did in the earlier group of post-Thornhill decisions: set the fact of the activity against the policy, and ignore the picketer's state of mind.

Although the First Amendment ought to be held to protect any form of expression that man may happen to devise to express his religious, political or social ideas, it would not seem to make much practical difference to judicial administration in the Court's picketing cases whether the above propositions were to be posited upon an independent constitutional right to picket or upon a derivative right based in freedom of speech. In either event, the qualification of "clear and present danger" reasoning would be applicable, and these propositions involve no more than applications of the abiding caution of that reasoning.

Although convinced of their efficacy, the writer has no illusions as to the significance of these several suggestions. Certainly, if adopted, they will result in no dramatic shifts of doctrine. Indeed, they seem to do little more than confirm the Supreme Court's present doctrine and add to it a note of caution in application. Vested interests of neither labor nor management are apt to be promoted by them except insofar as each is benefited by the kind of clarification which results in greater predictability of judicial action. If followed, they would enhance the possibility of an orderly and predictable pattern of judicial accommodation of what are customarily turbulent wants and needs to contemporary societal necessities. They would do this without discarding or enervating the constitutional right to picket and without trenching on proper state or federal legislative prerogatives in the distribution of economic power. 